\title{
139
}

Fahmi Irfanuddin, Fathurrahman Kamal, Cahyo Setiadi Ramadhan Fakultas A gama Islam, U niversitas M uhammadiyah Yogyakarta Jalan Brawijaya, Tamantirto, Kasihan, Bantul, Yogyakarta 55183

Email: fahmi.irfanudin@umy.ac.id

\section{Pemanfaatan Hasil Olahan Pertanian Berbasis Masjid}

\author{
A M osque B ased U tilization of Processed A gricultural \\ Products
}

https:/ / doi.org/ 10.18196/ bdr.7266

\begin{abstract}
The Regency of Kulon Progo has tourism and agriculture potentials. The same condition also applies to J atimulyo village which is one of the villages in Kulon Progo. Jatimulyo has a good agriculture potential, such as aren (sugar palm). J atimulyo has recently been developing after the access from the village to the city center had become better. As such, the society of the area needs to be encouraged to better improve. The society's potential that can be developed is business with the basis of processed agricultural products. To realize the goal, various society's empowerment programs are held to promote the society's awareness on distribution method so that their agricultural products can be competitive and can gain optimum profit. The programs are held through the methods of counseling, recitation, and a provision of stimulating fund. The results from the counseling given to mosque basis partners are transfer of knowledge on the urgency of processed agricultural products, farming group at Gunung Kelir, and variations of processed agricultural products.

Keywords: society's empowerment, mosque, transfer of knowledge, processed agricultural products.
\end{abstract}

\section{PENDAHULUAN}

Badan Pusat Statistik Kulon Progo (BPS, 2018a; 2018b) memberikan gambaran tentang berbagai wilayah di Kulon Progo, termasuk Kecamatan G irimulyo. Kecamatan tersebut merupakan kecamatan terluas keempat di Kulon Progo. Di sisi lain Girimulyo memiliki koperasi paling sedikit di Kulon Progo. Girimulyo juga tidak memiliki sentra industri terbina. Berdasarkan data tersebut dapat dikatakan masyarakat G irimulyo masih bersifat pertanian/ perkebunan Kondisi ini juga terlihat dari data BPS yang menyebutkan bahwa semua wilayah (desa) di Girimulyo masih bersifat pedesaan (rural).

Kondisi pertanian Girimulyo berhubungan dengan posisi Girimulyo di Kulon Progo Bagian U tara. D aerah tersebut memiliki kondisi geografi dataran tinggi yaitu perbukitan Menoreh yang memiliki ketinggian 500 - 1.000 M eter dari permukaan laut. Hampir setengah wilayah Girimulyo $(2.565,10 \mathrm{H}$ a) berada pada ketinggian lebih dari 500 meter. 
Lokasi di pegunungan menjadikan sebagian besar wilayah Girimulyo $(2.928,70 \mathrm{Ha})$ memiliki kemiringan lebih dari $40^{\circ}$. Seluruh wilayah $\mathrm{G}$ irimulyo berada pada posisi miring/landai walaupun hanya di bawah $2^{\circ}$. Pengaruh kondisi geografis tersebut terlihat pada kondisi pertanian G irimulyo dominan perkebunan (BPS Kulon Progo, 2018a).

Pertanian Girimulyo terlihat berpotensi untuk dikembangkan. $\mathrm{H}$ al tersebut merupakan modal alam (Flora dan A rnold, 2012). Di kecamatan tersebut terdapat pabrik gula kristal. Selain itu, pada kecamatan tersebut terdapat 11.368 petani dengan 5.330 orang menjadi anggota salah satu dari 110 kelompok tani di Girimulyo. Pada sisi lain, potensi tersebut terlihat kurang berkembang maksimal, sebagai contoh petani yang bergabung dalam kelompok tani tidak sampai setengah dari total jumlah petani. Selain itu juga, terdapat berbagai masalah hama yang mengganggu kegiatan pertanian. Sekitar 45,65 $\mathrm{H}$ a lahan terkena hama.

Berbagai potensi tersebut, termasuk potensi peternakan tidak otomatis berpengaruh pada konsumsi proten hewani perkapita masyarakat. Konsumsi telur yaitu 7,339 gram/ hari dan konsumsi daging yaitu 1,27 gram/ hari yang keduanya masih di bawah rerata masyarakat Kulon Progo. Masyarakat Girimulyo juga tercatat tidak mengonsumsi susu nonpabrik. $\mathrm{H}$ al ini menjadi indikator bahwa kondisi masyarakat $\mathrm{G}$ irimulyo masi $\mathrm{h}$ perlu ditingkatkan.

Selain terkait dengan kondisi mata pencaharian atau ekonomi, kondisi wilayah yang berbukit juga memengaruhi mobilitas dan aksesi bilitas masyarakat. Berdasarkan observasi diketahui bahwa alternatif jalan di kecamatan ini berbukit dan berkelok serta sebagian tidak dalam kondisi baik. Kondisi medan yang tidak mudah terlihat dari ketiadaan sambungan telpon kabel di kecamatan tersebut tidak ada sambungan telpon kabel yang kondisi tersebut merupakan satu-satunya di Kabupaten Kulon Progo. M asyarakat setempat menggunakan telekomunikasi selular untuk berkomunikasi.

Kondisi medan yang tidak mudah dipersulit dengan posisi kecamatan yang ada di perbatasan provinsi. Berdasarkan Peta Administrasi Lampiran Peraturan Daerah Kulon Progo Nomor 1 Tahun 2012 yang dapat dilihat pada lampiran, diketahui bahwa Kecamatan Girimulyo berbatasan utara dengan Kecamatan Samigaluh, sebelah Selatan dengan Kecamatan Pengasih, bagian Barat dengan Kabupaten Purworejo (Provinsi Jawa Tengah) dan sebelah Timur dengan Kecamatan Nanggulan.

Desa yang paling pinggir di G irimulyo yaitu Jatimulyo dan Purwosari yang keduanya langsung berbatasan dengan Jawa Tengah. D esa lainnya yaitu Pendowoharjo dan kemudian Giripurwo sebagai pusat kecamatan. Selain posisinya yang di pinggir provinsi, Jatimulyo 


\section{1}

juga memiliki keunikan yaitu sebagai satu-satunya wilayah yang memiliki banyak umat Buddha di Kulon Progo. Jatimulyo sendiri memiliki luas 16.2906 Km2 (29,67\% luas kecamatan) dengan jarak pusat Jatimulyo ke pusat Kecamatan Giripurwo yaitu $9 \mathrm{Km}$. Penduduk Jatimulyo sebanyak 6.754 jiwa dengan rerata 3 jiwa perkepala keluarga dan kepadatan 408 jiwa tiap Km2.

Berdasarkan wawancara diketahui bahwa masyarakat Jatimulyo juga cen derung bersifat agraris sebagaimana umumnya masyarakat Girimulyo, namun tidak didapatkan data tertulis mengenai kondisi pertanian. Berdasarkan hasil pengamatan terlihat kondisi pertanian mirip dengan umumnya kondisi pada tingkat kecamatan. Sebagaimana kondisi pertanian Girimulyo yang masih kurang maksimal, kondisi pertanian Jatimulyo juga mengalami kendala. Berdasarkan hasil wawancara, kesulitan mengembangan pertanian bersumber dari kurangnya pengetahuan mengenai pertanian. Padahal terdapat berbagai potensi yang dapat dikembangkan seperti peternakan kambing, kelinci atau budidaya jamur.

Berdasarkan wawancara awal diketahui bahwa untuk dapat meningkatkan kesejahteraan masyarakat melalui pertanian atau peternakan, diperlukan terbentuknya kelompok masyarakat setempat yang berkomitmen, memiliki pengetahun cukup, dan terbina untuk mengembangkan pertanian atau peternakan. $\mathrm{H}$ al tersebut sesuai dengan yang ditekankan A rcher, et al., (1984) serta Flora dan Flora (1993) bahwa pemberdayaan masyarakat perlu peran aktif masyarakat.

U ntuk mengembangkan masyarakat tersebut, dapat digunakan modal yang telah ada pada masyarakat (Flora dan Flora, 1993; Flora dan Arnold, 2012). M enurut Flora, salah satu modal yang ada pada masyarakat yaitu modal sosial dan bangunan. Bangunan sebagai tempat berkumpul dan perkumpulan sebagai kekuatan yang dapat digunakan untuk memberdayakan masyarakat tersebut. Pengembangan tersebut dapat memanfaatkan potensi berkumpul masyarakat yaitu di rumah ibadah yang umum ada di Jatimulyo yaitu masjid. Berdasarkan analisis situasi dan masalah yang telah dijelaskan sebelumnya, ditawarkan solusi yaitu "Pengembangan U saha Pertanian M asyarakat Berbasis M asjid/ M usala di Desa Jatimulyo, Kecamatan Girimulyo, Kabupaten Kulon Progo.".

\section{METODE PELAKSANAAN}

U ntuk dapat mencapai tujuan tersebut, perlu dilakukan beberapa langkah. $\mathrm{H}$ al yang pertama perlu dilakukan yaitu pendidikan kepada masyarakat mengenai prospek agribisinis masyarakat. Sosialisasi merupakan hal yang diperlukan dalam kegiatan 
pemberdayaan masyarakat. C avaye (dalam Shaffer, 2015) menyatakan bahwa pengetahuan merupakan hal yan gutama dalam pemberdayaan masyarakat. $\mathrm{H}$ al ini juga sesuai dengan struktur manusia yaitu perlu mengetahui terlebih dahulu untuk menimbulkan perubahan kecenderungan perilaku (Bandura, 1977).

Untuk itu, dalam program ini langkah pertama yangjuga tercermin dari tujuan pertama program ini yaitu meningkatkan pengetahuan masyarakat mengenai agribisnis. U ntuk itu masyarakat akan dikumpulkan di masjid sebagai modal ban gunan mereka (built capital) dan diterangkan oleh fasilitator mengenai prospek agribisnis yang sesuai dengan modal alam mereka (natural capital) (Flora dan Flora, 1993; Flora dan Arnold, 2012).

Setelah mendapatkan edukasi, masyarakat yang terkumpul melakukan FGD untuk merumuskan langkah yang akan mereka lakukan selanjutnya. $\mathrm{H}$ al ini diperlukan karena sebagaimana yang disampaikan sebelumnya bahwa penting dalam pemberdayaan masyarakat mereka terlibat (Archer, et al.; 1984; C avaye, 2015; Flora dan Flora, 1993). Dalam hal ini pengusul akan menyediakan fasilitator yang mengarahkan jalannya diskusi yang berujung pada pembentukan kelompok tani.

Setelah terkumpul, masyarakat didorong untuk melakukan pembentukan kelompok usaha tani. Langkah ini sebagaimana program secara umum dimulai dari edukasi. Kepada masyarakat dilakukan edukasi peningkatan daya jual. M asyarakat yang terkumpul menjadi masyarakat yang dapat ditagih komitmennya sehingga dapat dikenai peningkatan kemampuan. Pada proses perubahan, adanya suatu penanda komitmen diperlukan untuk keberhasilan sebuah perubahan (M ilten berger, 2015). Kelompok ini mendapatkan edukasi peningkatan daya jual produk taninya melalui proses edukasi dan pendampingan hingga ketahap praktik.

Proses praktik merupakan proses belajar sosial dari materi edukasi yangtelah dilakukan. U ntuk itu, kelompok yang telah terbentuk menjalankan langkah yang telah diketahui dari proses edukasi secara terbimbing. Proses ini efektif untuk pemula yang sedang melakukan peningkatan kapasitas diri (C orrey, 2012; Milten berger, 2015). Terjadinya peningkatan kapasitas kelompok menunjukkan tercapainya tujuan program.

Setelah berakhir periode program, kegiatan dapat terus dilanjutkan dalam dua cara yaitu terjadinya mekanisme vicariouslearning (Bandura, 1971). Peningkatan kapasitas rekan dari lingkungan sekitar menimbulkan proses pembelajaran melalui mencontoh sehingga masyarakat mencontoh kelompok yang telah ada dan kegiatan agribisnis serupa muncul di lingkungan desa. Ini akan mendorong peningkatan ekonomi desa sehingga meningkatkan kapasitas desa sendiri sebagai mana yang ditunjukkan oleh Convey (2015). 


\section{3}

Pengaruh saling memengaruhi tersebut juga sesuai teori Bronfenbrenner (1979). Walaupun dapat terjadi secara alamiah, tetapi penyebaran tersebut akan tetap dikontrol sebagai bagian dari experiential learning masyarakat dan pelaksana program sebagai ahli tempat masyarakat bertanya atau memberikan saran kepada masyarakat.

\section{HASIL DAN PEMBAHASAN}

Pada proses pelaksanaan terjadi berbagai perubahan. $\mathrm{H}$ al ini wajar karen a proses dalam program di masyarakat terlihat seperti siklus dalam Action Research (Koentjoro, Sadewo, dan Andayani, 2016; Velasco, 2013). Prosesnya sirkular dan perubahan tersebut menjadikan pengabdi menyusun ulang kegiatan. Perubahan ini juga didukung waktu penilaian awal yang singkat sehingga saat pengabdi mulai turun ke lapangan, terlihat berbagai data baru. Data tersebut menunjukkan perlunya dilakukan perubahan kegiatan.

Berdasarkan pendekatan masyarakat diketahui bahwa masyarakat cenderung antusias untuk mengembangkan usaha olahan pertanian daripada belajar mengenai pertanian. M asyarakat juga telah memiliki cara pertanian yang cukup untuk produk-produk pertanian lokal seperti gula batok (gula merah). Produk pertanian masyarakat telah ada, termasuk gula merah, tetapi tidak diolah secara baik. $\mathrm{Hal}$ ini menjadikan nilai jual dan tingkat kemenarikannya tidak maksimal.

Kondisi ini menjadikan kegiatan pengabdian akan berfokus pada peningkatan nilai jual dan daya pemasaran produk pertanian dengan tetap berdasarkan kepada masjid sesuai tema pengabdian. Kelompok yang dibentuk bukan berupa kelompok tani tetapi kelompok ekonomi.

1. Pendekatan masyarakat dilakukan sejak 29 Januari 2019 hingga sekarang oleh empat mahasiswa dengan satu orang tinggal sebagai pengurus M asjid Baiturrahman Branti.

2. Pendekatan pemerintah juga dilakukan selain pendekatan kepada masyarakat, yaitu kepada musyawarah pimpinan desa seperti Kepala D esa, unsur kepolisian, unsur KUA, dan Kepala Dukuh. Kegiatan ini diperlukan untuk memperlancar kegiatan kepada masyarakat. Kegiatan dilakukan pada pada 31 D esember 2018 dan 2-5 M aret 2019.

3. Sosialisasi Peningkatan Nilai Jual Produk Pertanian merupakan modifikasi dari kegiatan awal Sosialisasi Agribisnis. Kegiatan ini telah dilakukan pada 9 Februari 2019 pukul 10.00 - 12.00 W IB dengan pembicara praktisi pengemasan D ani D ardanela dari Pojok Kemasan. Kegiatan dilaksanakan di M asjid Baiturrahman Branti. Praktisi juga memotivasi masyarakat untuk meningkatkan nilai jual produknya.

4. Focus Group Discussion (FGD) atau diskusi kelompok terfokus dilakukan pada 25 
Februari 2019 dengan fasilitator. Fokus diskusi adalah mengenai upaya meningkatkan kemampuan ekonomi masyarakan secara bersama. Terlihat kesulitan masyarakat untuk mendapatkan stimulus maju bersama. Ada kecen derungan men gan dalkan pemberian dan senang untuk maju masing-masing.

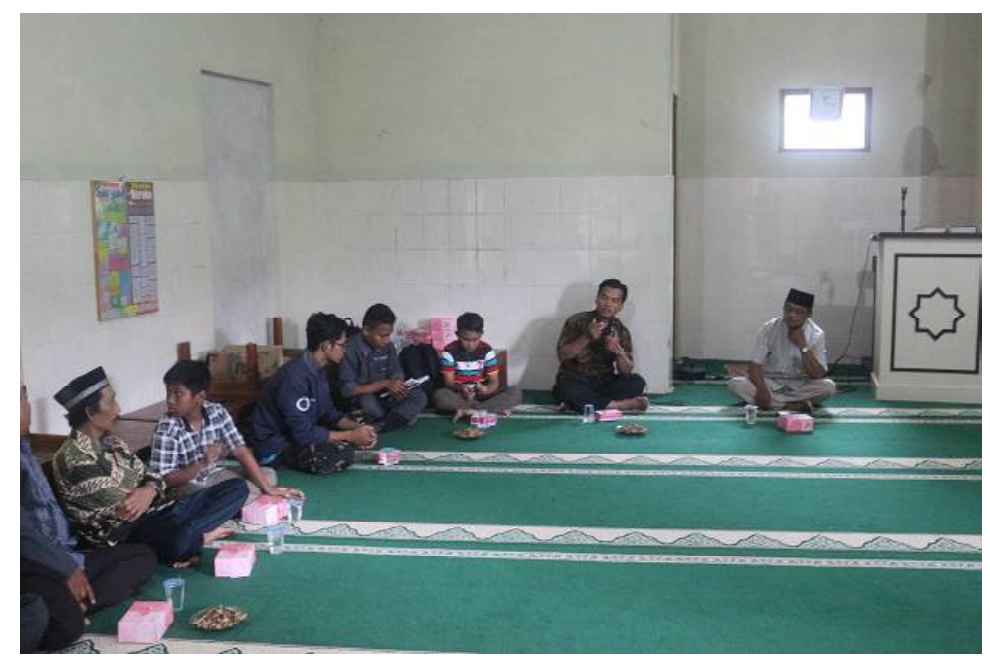

Gambar 1. Peningkatan Motivasi Spiritual

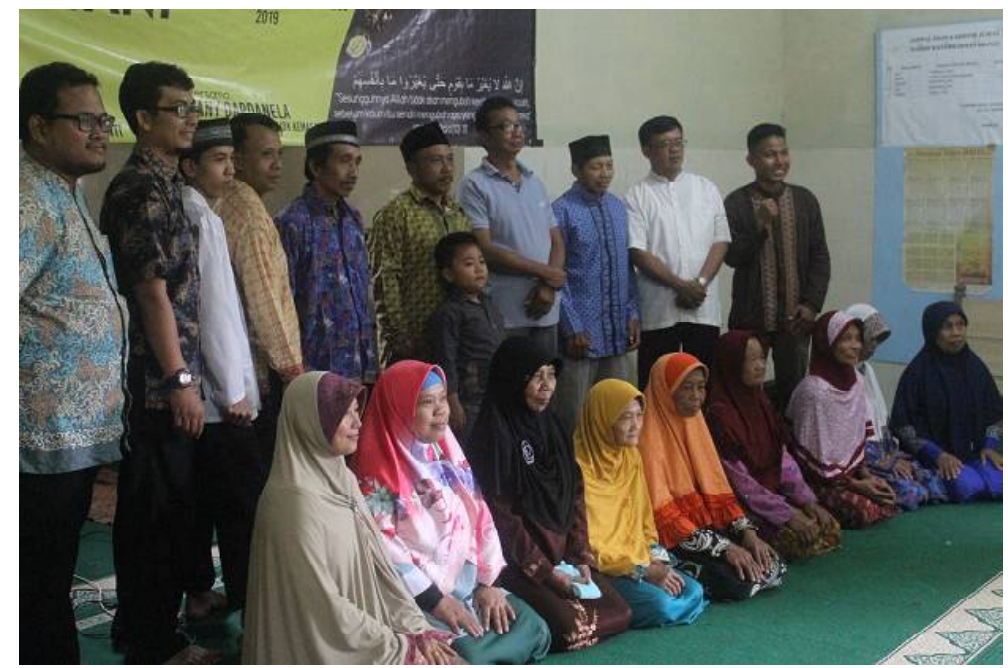

Gambar 2. Kegiatan Pembentukan Kelompok Usaha

5. Pembentukan KelompokU saha melalui D iskusi Kelompok Terfokus Kedua. Kegiatan FGD Pertama belum mampu mendorong masyarakat untuk berkelompok. Kegiatan ini difasilitasi oleh anggota tim mahasiswa dan dilakukan pada 12 M aret 2019 pukul 19.30-21.00 di Masjid Baiturrahman Branti.

6. Edukasi Kelompok U saha dilakukan sebagian pada 8 Maret 2019 oleh praktisi. 


\section{5}

Kegiatan dilakukan di M asjid Baiturrahman Branti. Praktisi fokus pada peningkatan daya jual produk dengan metode ceramah dan experiential learning parsial. Dilakukan juga edukasi kepada kelompok secara parsial pada 25 Februari 2019 mengenai nilai ibadah pada usaha ekonomi dan perintah Allah Swt. untuk bekerja kelompok (team work) dengan metode FGD forum besar.

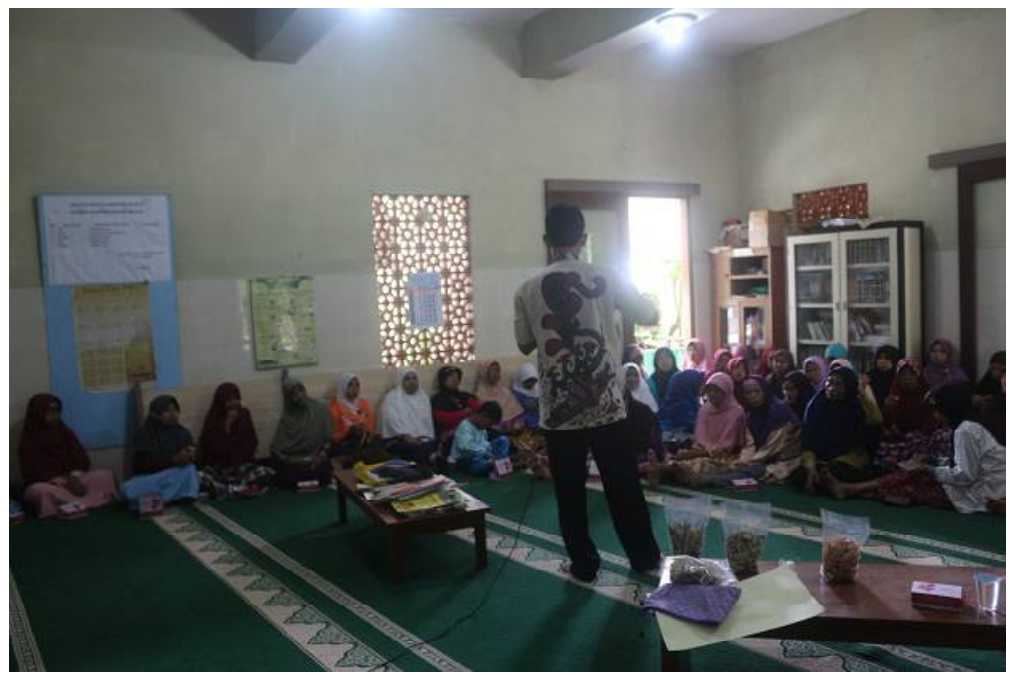

Gambar 3. Masyarakat Mengikuti Edukasi Dengan Saksama

7. Penyerahan modal dan penjelasan sistem kelompok dilakukan pada 20 A pril 2019 pukul 11.30-13.30 WIB di M asjid Baiturrahman Branti. Sistem yang akan dilakukan yaitu anggota kelompok dapat menggunakan modal kelompok untuk kegiatan usaha (produktif) dengan aqad qardh hasan yaitu pinjaman yang akan dikembalikan lagi untuk digilirkan pada peminjam yang lain. Pada kegiatan ini kembali dilakukan peningkatan motivasi spiritual masyarakat untuk berusaha mandiri dan berdikari.

8. M odeling peningkatan daya jual produk merupakan perluasan dari metode experiential learning dalam edukasi kelompok usaha. Inti kegiatan ini yaitu Kelompok U saha dibantu tim mahasiswa, praktisi, dan juga pengabdi dalam upaya meningkatkan produknya. Kegiatan ini berlangsung sejak $8 \mathrm{M}$ aret 2019 hingga sekarang berupa pengemasan produk dan foto produk. Selain ini akan dilakukan juga perluasan pasar dengan memasukkan produk ketempat pemasaran baru bahkan melalui media sosial. Berbagai kegiatan tersebut menjadikan masyarakat Branti, G unungkelir memahami pentingnya usaha pertanian dalam kehidupan diusahakan melalui serangkaian kegiatan edukasi. M asyarakat telah men dapatkan pengetahuan (transfer of knowledge) urgensi usaha berbasis hasil pertanian maupun usaha yang umum lainnya. Tingkat kepahaman masyarakat terlihat dari kesediaan sebagaian anggota masyarkat untuk memproduksi 
berbagai produk olahan hasil pertanian dan membentuk kelompok usaha. Selain itu dari hasil wawancara tidak terstruktur kepada anggota masyarakat terlihat ada kepahaman mengenai urgensi usaha berbasis hasil pertanian.

Selain itu, muncul kelompok usaha tani di Gunungkelir di lokasi terdapat masjid telah tercapai walaupun tidak diikuti semua warga masyarakat. M asyarakat mengetahui penambahan nilai jual produknya melalui kegiatan edukasi kelompok usaha dan modeling peningkatan daya jual produk dengan bantuan praktisi. M ereka dibimbing untuk menetapkan harga yang lebih tinggi dengan adanya peningkatan nilai jual produknya.

Setelah program berakhir, komunikasi dan pemantauan aplikasi pengetahuan yang telah diterima perlu dilakukan. Selain itu, terdapat hal-hal yang dapat ditindaklanjuti dari kegiatan ini yaitu memperkuat kelompok usaha dengan melakukan pembenahan manajemen dan organisasi kelompok terlebih dalam hal perputaran dana.

\section{SIMPULAN}

Pelatihan dan pendampingan kelompok menjadikan masyarakat Branti memperoleh pengetahuan (transfer of knowledge) urgensi usaha berbasis hasil pertanian, terwujudnya kelompok usaha tani, serta mampu membuat varian produk olahan hasil pertanian.

\section{UCAPAN TERIMA KASIH}

Terima kasih disampaikan kepada Lembaga Penelitian, Publikasi dan Pengabdian M asyarakat (LP3M) Universitas M uhammadiyah Yogyakarta yang telah membiayai kegiatan ini. D emikian juga kepada segenap tokoh masyarakat yaitu kepada Kepala D esa Jatimulyo, Kapolsek Girimulyo, dan segenap perangkat pedukuhan G unungkelir yang telah mendukung terlaksananya program. Selain itu, disampaikan juga terima kasih kepada segenap masyarakat Branti, Gunungkelir, Jatimulyo, Girimulyo yang telah bersedia menjadi mitra program dan menjalani perubahan bersama tim pelaksana program. Terkhusus terima kasih disampaikan kepada Takmir Masjid Baiturrahman Branti, Pak Siran, dan segenap warga masyarakat Branti.

\section{DAFTAR PUSTAKA}

Archer, S. E., Kelly, C. D., dan Bisch, S. A. 1984.

Planning and Change Processes. Implementing

Change in Communities: A Collaborative Process.

St. Louis: The C.V. Mosby Company.

Badan Pusat Statistik (BPS) Kabupaten Kulon Progo.

2018a. Kabupaten Kulon Progo Dalam Angka

2018. Yogyakarta: Penyusun.
Badan Pusat Statistik (BPS) Kabupaten Kulon Progo.

2018b. Kecamatan Girimulyo Dalam Angka 2018. Yogyakarta: Penyusun.

Bandura, A. 1971. Social Learning Theory. New York: General Learning Press.

Bandura, A. 1977. "Self-Efficacy: Toward A Unifying Theory Of Behavioral Change". Psychological 
Review, 84: 191-215.

Bronfenbrenner, U.1979. The Ecology Of Human Development: Experiments By Nature And Design. Cambridge, MA: Harvard University Press.

Cavaye, J. 2015. Understanding Community Development. Quensland: Cavaye Community Development

Correy, G. 2012. Theories And Practice Of Counselling And Psychotherapy. Belmont: Brooks-Cole Cengage Learning.

Flora, C.B., \& Flora, J.L. 1993. Entrepreneurial social infrastructure: A necessary ingredient. Annals of the American Academy of Political and Social Sciences 539: 48-58.

Flora, C., \& Amold, N. 2012. Community Development. State of The Science Report. Montana: RTCRural The University of Montana.

Miltenberger, E.G. 2015. Behavior Modification: Principles and Procedures. Belmont: Cengage Learning.

Koentjoro, Sadewo, P. H., Andayani, B. 2016.

Community Engagement or Community Development. Presentasi pada The 10th Global Regional Centres of Expertise on Education for Sustainable Development (RCEs on ESD) 23 - 25 November 2016, Universitas Gadjah Mada, Yogyakarta, Indonesia.

Velasco, X. C. 2013. Participatory Action Research (PAR) for Sustainable Community Development. Dilihat pada 23 J uni 2019 dari postgrowth.org. 